Patients with PvSS are often considered for rib resection, especially when symptoms persist despite thrombolysis and anticoagulation when balloon angioplasty may improve flow pending surgical decompression. ${ }^{7}$ However, not all patients require surgery. ${ }^{8}$ Following decompression, if the vein remains narrowed, balloon angioplasty and stent placement have been shown to have good long-term results. ${ }^{9}$

Paget-von Schroetter syndrome usually occurs in young, healthy individuals. Prompt recognition and referral for urgent imaging enables treatment to re-canalise the vein and may prevent venous thrombosis if identified at the 'herald symptom' stage. Surgical assessment enables consideration for rib resection if necessary.

\section{References}

1 Hughes ESR. Venous obstruction in the upper extremity. (Paget-von Schrotter's syndrome): a review of 320 cases. Int Abst Surg 1949;88: $89-127$.

2 Zell L, Kinderman W, Marschall F et al. Paget-von Schrotter syndrome in sports activities - case study and literature review. Angiology 2001; 52:337-42.
3 Roos DB. Congenital anomalies associated with thoracic outlet syndrome: anatomy, symptoms, diagnosis, and treatment. Am J Surg 1976;132:771-8.

4 Demondion X, Boutry N, Drizenko A et al. Thoracic outlet: anatomic correlation with MR imaging. Am J Roent 2000;175:417-22.

5 Ali F, Abu Rhama AF, Sadler D, Stuart P, Conventional versus thrombolytic therapy in spontaneous (effort) induced axillary vein thrombosis. Am J Surg 1991;6:459-65.

6 Maintz D, Landwehr P, Gawenda M, Lackner K. Failure of Wallstents in the subclavian vein due to stent damage. Clin Imaging 2001;25:133-7.

7 Sharafuddin MJ, Sun S, Hoballah JJ. Endovascular management of venous thrombotic diseases of the upper torso and extremities. J Vasc Int Rad 2002;13:979-90.

8 Lokanathan R, Salvian AJ, Chen JC et al. Outcome after thrombolysis and selective thoracic outlet decompression for primary axillary vein thrombosis. J Vasc Surg 2001;33:783-8.

9 Kreienberg PB, Chang BB, Darling RC III. Long-term results in patients treated with thrombolysis, thoracic inlet decompression, and subclavian vein stenting for Paget-Schroetter syndrome. J Vasc Surg 2001;33:S100-5.

\title{
Literature and medicine
}

\section{Medical anthropology in Jane Austen's Emma}

\author{
Neil Vickers
}

Jane Austen's interest in medicine is well known. Her comic masterpiece Emma, first published in 1815, wears its medical interests on its sleeve with references to health and sickness found in every chapter. ${ }^{1}$ And yet the novel seems oddly and knowingly reticent about its medical content.

Perhaps the most striking feature of the little group Austen describes is the way it responds to sickness. Emma's father, Mr Woodhouse, is a hypochondriac who devotes every waking moment to health worries. He urges those around him to adopt his regimen of thin gruel, warm rooms and comically moderate exercise. Much of his time is spent in consultation with the local apothecary, Mr Perry, who if Mr Woodhouse is to be believed - acquiesces in all his patient's opinions. (But Woodhouse is a bad listener, 'he could never believe other people to be different from himself' (16), and we never hear Perry say anything in his own voice. His deeds and sayings are only ever reported.)

Mr Woodhouse attributes his survival into late middle age to a life of extreme caution and to Perry's ministrations. Austen archly describes Mr Woodhouse as 'a valetudinarian all his life, without activity of mind or body' (5); if he has any physical complaint, the book does not disclose it. Mentally he seems blocked. He hates to leave his own house and he dislikes making new acquaintances. When he takes a walk he makes it a rule never to go beyond his shrubbery. He commiserates with his friend Mr Knightley on having walked half a mile in the moonlight. And he lives in constant fear of catching colds.

What appears to irk Mr Woodhouse more than anything else is marriage. Early on in the novel we find him depressed that Miss Taylor, who had acted as governess since his wife's death 16 years earlier, has left him to marry one of his neighbours, Mr Weston. The marriage is a source of joy to everyone but him. 'Ah! poor Miss Taylor!' he exclaims, 'tis a sad business' (16). The couple make him a present of a large portion of their wedding cake. When his daughter invites their friends to share it, he earnestly tries 'to dissuade them from having any wedding-cake at all, and when that proved vain, as earnestly tried to prevent any body's eating it'. The 
ostensible reason is that the cake is too rich but the reader is left in little doubt that it is marriage Mr Woodhouse cannot swallow. He feels the same pity for his eldest daughter Isabella who is married to Knightley's younger brother. 'Poor Isabella' he calls her. When Emma and her friend Harriet Smith begin poring over verse puzzles about courtship and marriage he can remember only one: David Garrick's 'Kitty, a fair but frozen maid' (63). It is one of the few thoroughly ribald moments in the Austen oeuvre. $\mathrm{Mr}$ Woodhouse's detestation of marriage forms a crucial backdrop to his daughter's disastrously blundering attempts at matchmaking.

The Harvard anthropologist and psychiatrist Arthur Kleinman has observed that one of the most distressing aspects of having a chronic disease today is that sooner or later those close to you will doubt whether you are really ill. ${ }^{2}$ The sick role in Regency Surrey (played out in the village of Highbury) as described by the early 19th century medical anthropologist Jane Austen was very different - though, admittedly, hers was a microstudy of 'two or three families in a country setting. Highbury society never questions whether Mr Woodhouse is really ill and neither does it laugh at his medical obsessions. It is not simply that, as in Talcott Parsons' famous formulation, the person who declares himself sick ceases to be accountable to his peers. ${ }^{3}$ Illness in Emma is represented as a zone of mystery almost on a par with the supernatural. There is no questioning the illness of a loved person in Highbury, real or shammed.

In this respect, the cases of Jane Fairfax and Mrs Churchill are instructive. Mrs Churchill is the aunt of Mr Weston's son and his adoptive mother and is Mr Woodhouse's demonic double. Where he is indulged, she is reviled. The first sentence in which she is named mentions her certain 'ill-humour' (109). She is depicted as a tyrant for demanding that all around her fall in with her little ways. The same vice in Mr Woodhouse is portrayed humorously and affectionately. At a crucial point in the novel she falls ill with an unspecified disease which is said to make her very weak (again, we are in the realm of hearsay). Nobody in Emma's set criticises her except Mr Weston, an indiscreet man who has reason to resent her. His son too refers somewhat uncharitably to 'the wilful or nervous part of her disorder' (though he is convinced she is genuinely ill). Mrs Churchill's sickness can be questioned because she is not loved. There are wonderful multiple ironies in the fact that when she dies, thereby proving that she was not feigning (and just as importantly, freeing her nephew to marry his fiancée), the only person to express sorrow is Mr Woodhouse.

Though Jane Fairfax is a young woman in the prime of life, her impoverished aunt and grandmother spend much of the novel willing her into the role of patient. She arrives in Highbury with a cold and straight away the reader is made to feel that she could waste away in a matter of pages. Over time, it becomes clear that Jane Fairfax plays up to her image as a frail vessel because she is secretly engaged to Frank Churchill and wants to restrict social relationships in case she gets quizzed about him. As with Mr Woodhouse, no one behaves in a way that suggests she is not ill. Frank Churchill's first remarks about her concern her 'deplorable want of complexion' (178) but he, we suspect, is attempting to consolidate her standing as a valetudinarian. By the end of the novel he rhapsodises about her complexion: 'Such smoothness! Such delicacy!' (434).

The opacity and unpredictability of sickness in cases such as $\mathrm{Mr}$ Woodhouse's and Mrs Churchill's (no one in the novel considers diagnosis desirable) seem designed to teach a moral lesson about people in general. Through them Austen depicts the fusion of sickness with personality and lifestyle and is saying perhaps that speculating about illnesses of these kinds is like speculating about who will marry whom. Events will always take you by surprise, no matter how judiciously you frame your suspicions. What would the early 19th century physician have said if consulted by Mr Woodhouse? Highbury's silence in the face of $\mathrm{Mr}$ Woodhouse's absurd lifestyle is not simply gallant but wise.

\section{References}

1 Austen J. Emma. Oxford: Oxford University Press, 2003.

2 Kleinman A. The illness narratives: suffering, illness and the human condition New York: Basic Books, 1988.

3 Parsons T. The social system. New York: Free Press, 1951. 